症例

肝細胞癌との鑑別に難漇した右尾状葉原発肝血管腫の 1 切除例

\author{
大同病院外科 \\ 梛野正人近藤成彦金井道夫 \\ 森光 平 \\ 名古屋大学第 1 外科 \\ 二村雄次向山博夫神谷順一
}

症例は56歳の女性で, 血尿の精査にて入院中, 腹部超音波検査にて肝腫瘤が発見され

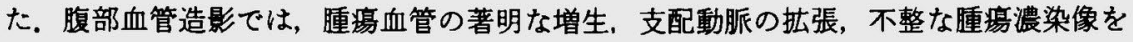
認めた。 Angio-CT では，畽湯は造影剂注入直後から中心部以外は，ほ泳均一に濃染し， その濃染が経時的に中心部にも移行してゆく像を認めた. Angio-CT からは, 肝血管腫も 強く示唆されたが, 血管造影, 特に腫瘍血管の著明な増生像より, 肝細胞癌々診断し手 術を施行した。畽瘍は右尾状葉に存在し，尾状葉全切除を伴ら左葉内側区および右葉前 上区域切除といら非定型的術式にて切除しえた。病理組織学的には, 腫瘍は肝海綿状血 管畽で，悪性像は認められなかったが，畽瘍の被膜外に動脈枝を多数認め，血管造影の 所見をよく反映していると考えられた，血管造影上，肝細胞癌との鑑別が困難な肝血管 畽が存在する点に留意すべきである.

索引用語：肝血管腫, 血管造影, 腫場血管

はじめに

血管造影上, 支配動脈の抬張, 腫汮血管の増生といっ た肝細胞癌類似の所見を呈した肝海綿状血管腫の 1 切 除例を経験したので，両者の画像診断上における鑑別 を中心に若干の考察を加えて報告する.

症例

患者：56歳，女性.

主訴：血尿.

家族歴：特記すべきことなし。

既往歴：特記すべきことなし。

現病歴：昭和60年 6 月下旬より血尿に気つさ， 7 月 10日精查のため当科入院となった，血尿の原因は，㘖 胼鏡, 経静脈性堅昷膀胱造影などから出血性膀腅炎と 診断したが，腹部超音波検查にて肝に腫瘤が発見され た.

入院時現症：体格中等. 栄養良. 負血 (一). 黄疸 ( - ). 胸部理学的所見異常なし、腹部は平坦, 軟で, 訮, 脾, 尰瘤を触知しない。

入院時検查成績：尿検查で赤血球（卅）である以外，

昭和62年 5 月 16 日受付 62 年10月26日採用
異常を認めなかった。腫瘍マーカーも CEA 0.5ng $/ \mathrm{ml}$, AFP 2ng $/ \mathrm{ml}$, CA19-9 12U/ml, Ferritin $64.1 \mathrm{ng} / \mathrm{ml}$ と正常であった.

腹部超音波検查(図 1 )：左葉内側区頭側に, $65 \times 54$ $\mathrm{mm}$ と $25 \times 16 \mathrm{~mm}$ の境界明瞭な類円形の腫瘤が 2 コ存 在し，右および左肝静脈を王排していた，中肝静脈は

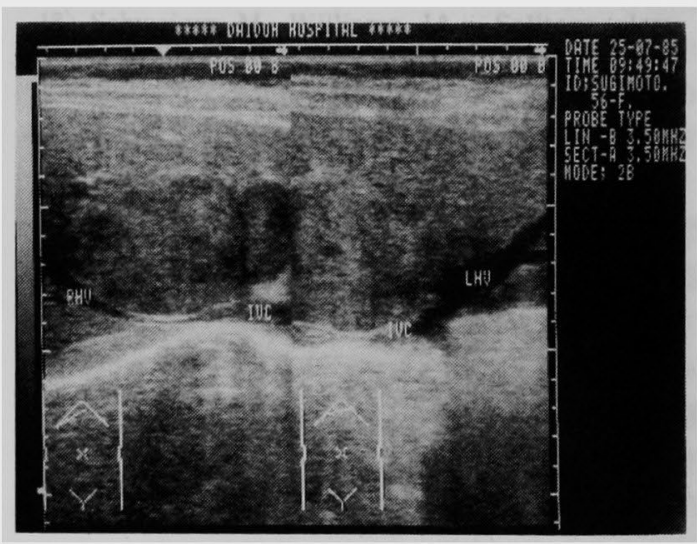

図 1 腹部超音波像：腫瘍は，類円形で右および左肝 静脈を王排している。

IVC : 下大静脈, RHV : 右肝静脈, LHV : 左肝静脈 
描出できなかった。畽瘤の内部は全体に肝実質と同程 度のエコーレベルで, 内部に小さな低ェコー部を認め たか，質的診断は困難であった。

畈シンチグラム：左葉内側区頭側に，陰影欠損像が 認められた。

腹部血管造影(図 2a, b, c)：動脈相では，屈曲，蛇 行した腫疸血管の豊富な增生を，静脈相では，不整な 稙湯袽染像を認めた。畽湯は，中肝動脈，右肝動脈前 上区域枝からす栄盖されていたが，主支配血管は著明 に拡張した右尾状葉枝であった。経動脈性門脈造影で

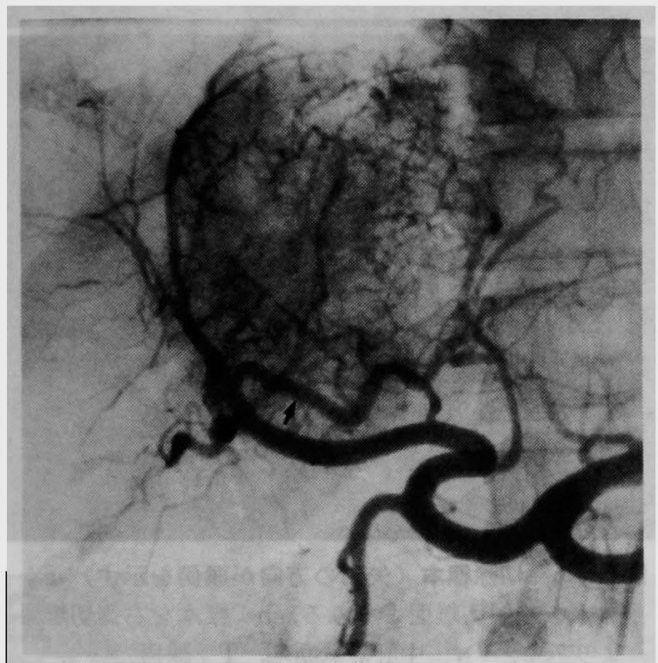

图 2a 腹部血管造影像（動脈相）：腫場血管の著明な 增生を認める。 八は执張した右尾状葉動脈枝。

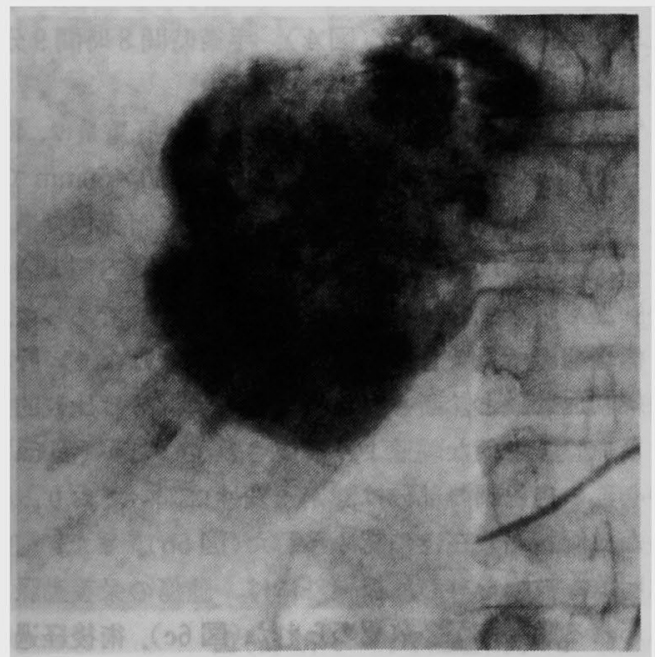

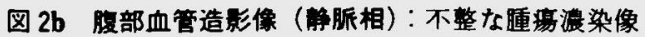
を認める。

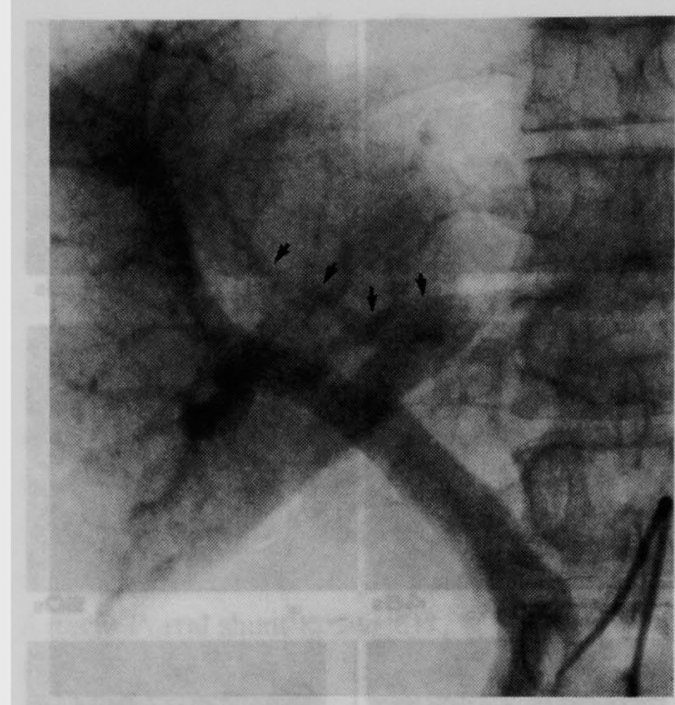

図 2c 経動脈性門脈造影像：矢印に示すように左葉 内側区門脈枝に圧排所見を認める。

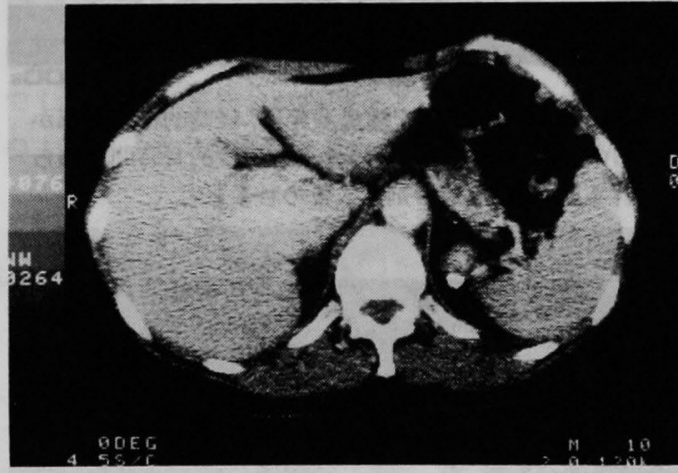

図 3a CT 像 $(\mathrm{CE})$ : 腫瘍は肝門部と下大静脈の間に 位置している。

は，左葉内側区門脈枝に压排所見を認めたか，門脈内 畽瑒栓は認めなかった。

Computed Tomography（以下, CT）：主腫煌は, 肝門部と下大静脈の間, やゃ右側に存在しており，右 尾状葉原発と診断した(図 3a)，カテーテルを固有肝動 脈まで插入して施行した Angio-CT では，腫場は造影 剤注入直後から中心部以外はほぼ均一に濃染し，その 濃染は経時的に中心部にも移行し，比較的長時間にわ たって認められた（図 3b).

以上, 画像診断では, Angio-CT からは肝血管腫も考 虑されたか，血管造影像より右尾状葉原発の肝細胞癌 と診断した。 

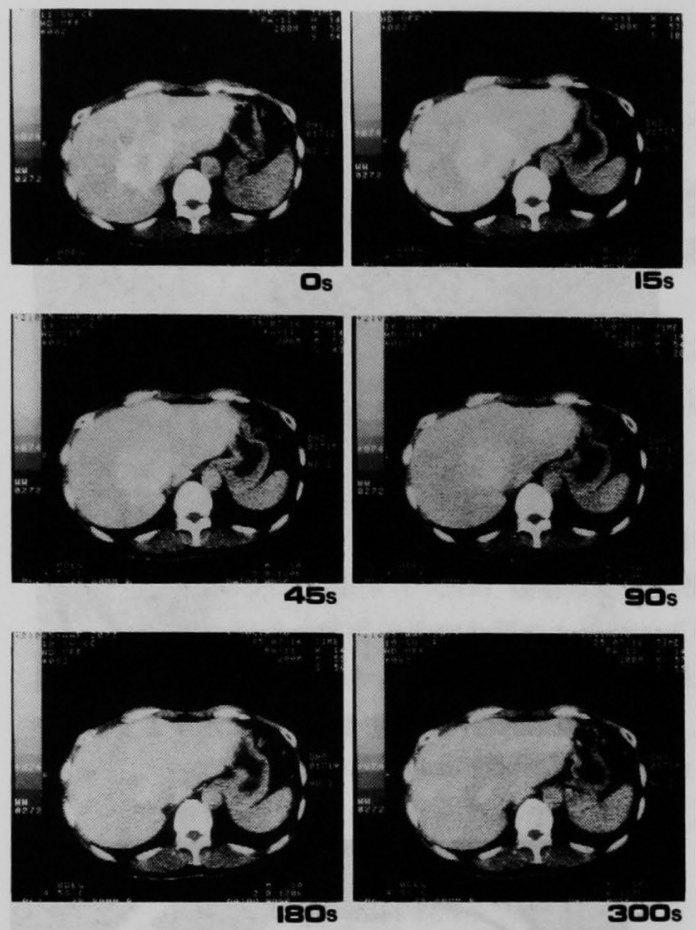

図 3b Angio-CT 像 : 腫瘍濃染は, 経時的に周辺部か ら中心部へ拡がり，その濃染は比較的長時間認めら れる.（数字は造影剤注入後の秒数）

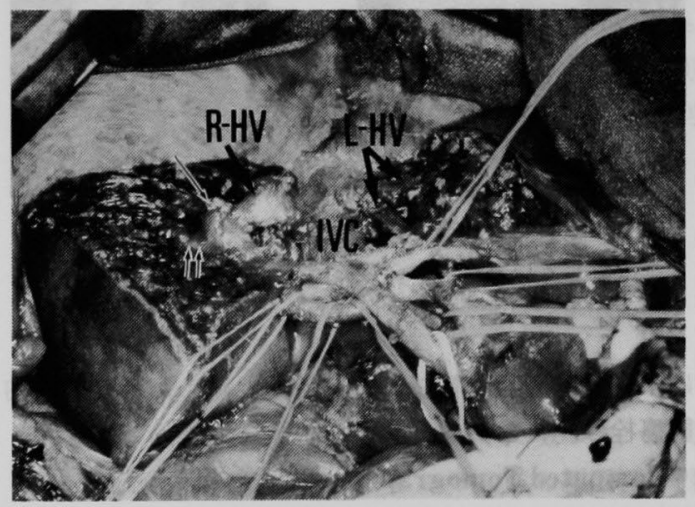

図 4 手術終了図：尾状葉全切除を伴ら払大内側区域 切除術.

IVC : 下大静脈 R-HV : 右肝静脈, L-HV : 左肝静 脈, 〉: 右葉前上区域グリンン断端, ノノ：右葉前 下区域グリンン

手術所見：8 月 5 日, 両側季肋下切開にて開腹. 肝 硬変 (一). 腹水 (一). 尾状葉の腫湯は肝表面から全 く同定できなかったが，他に，左葉内側区の横隔膜側
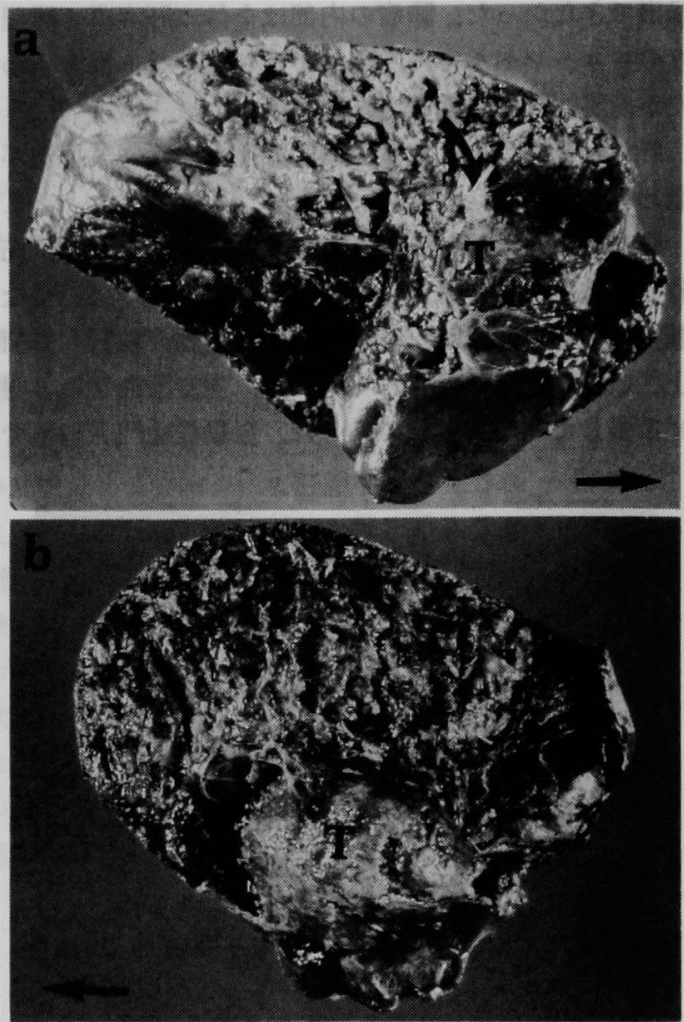

図 5a, b 切除標本 (矢印の方向が頭側を示す) : a 標本を左側切離面よりみる， b : 標本を右側切離面 よりみる。（〉：中肝静脈断端， $\mathrm{T}$ ：腫瘍）

にクルミ大の腫場が認められた，尾状葉全切除を伴ら 拡大内側区域切除術（尾状葉+左葉内側区十右葉前上 区域切除術)を施行した(図 4 ). 手術時間 8 時間 9 分, 出血量3.756ccであった。

切除標本肉眼所見(图 5a, b, c): 切除肝重量は, 420 g. 主腫湯は右尾状葉を占居し，大きさ $60 \times 50 \mathrm{~mm}$ で, 正常肝組織とは明暸に区別され，全体に暗赤色であっ たが，中心部は白色調を呈していた。左葉内側上区の 小隀掦も暗赤色を呈し，主腫場と同じ性状であった。

病理組織所見：2 コの腫場とも悪性像はなく，肝の 海綿状血管腫と診断された. 腫湯の大部分は比較的大 きな血管腔と眯な隔壁より構成されていたか（图 6a)， 中心部の白色調の部分は, 硝子変性に陥っており, 小 さな血管挖が散在性に認められた(图 6b). また, 腫瘍 は明瞭な被膜を有し, 被膜外には, 睡湯の栄養動脈之 思われる動脈枝が多数認められた(図 6c). 術後経過は 良好で, 術後13カ月の現在, 元気に社会復帰している。 


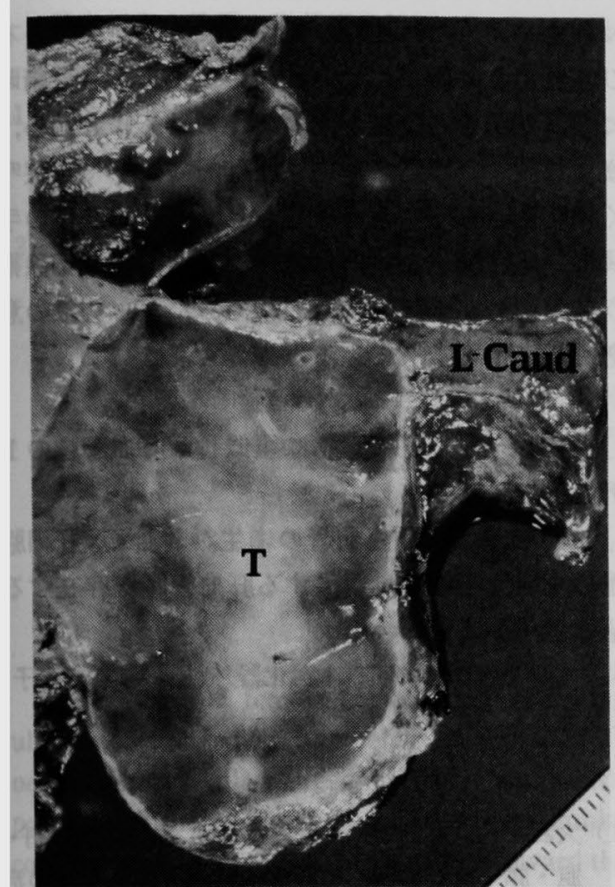

图 5e 切除標本割面像：主腫瘍（T）が右尾状葉原発 であることがよくかかる.（L-Caud：左尾状葉）

\section{考 寨}

血管造影上，肝血管腫に最も特徽的な所見は，動脈 相に出現し，静脈相にまで持続する点状ないし斑状の 密な濃染像とその濃染像が経時的に増大する傾向を示 すことである ${ }^{1) 31}$ ，血管腫にお゙ける腫瘍の支配動脈の 拡張の有無は, 腫瘍の vascularityに関連し", vascularity の多い腫湯では支配動脈は扗張することすあ るが一般には, 正常径か, 払張していても軽度なことが 多く1)4，大きな血管腫では畽湯の王排，伸展のため逆

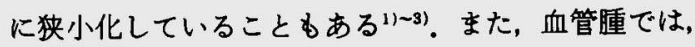
通常, 畽湯血管の増生は認められないとされている $か^{(1) 3) 4)}$ ，届瘍血管の増生を示し，血管造影上, 肝細胞癌 と㝿めて類似した症例も報告されている3(5) 7). Arterio-Portal shunt については, 従来, 肝細胞癌に特 徵的で，血管腫には稀とされているが899)，石ロら”は， 40例の肝海綿状血管腫のうち4例（10\%）にこれを認 めておりそれほど稀な所見ではないと報告している。 また, 最近では Lipiodolを併用した動脈造影が主に肝 細胞癌に対して施行されているが, Lipiodolの集積は 肝細胞癌に特徵的とは言えず(0), われわれる肝血管腫 で Lipiodol の集積した症例を $2 ， 3$ 経験している。こ のように, 多少の例外はあるものの, 肝血管腫の大部

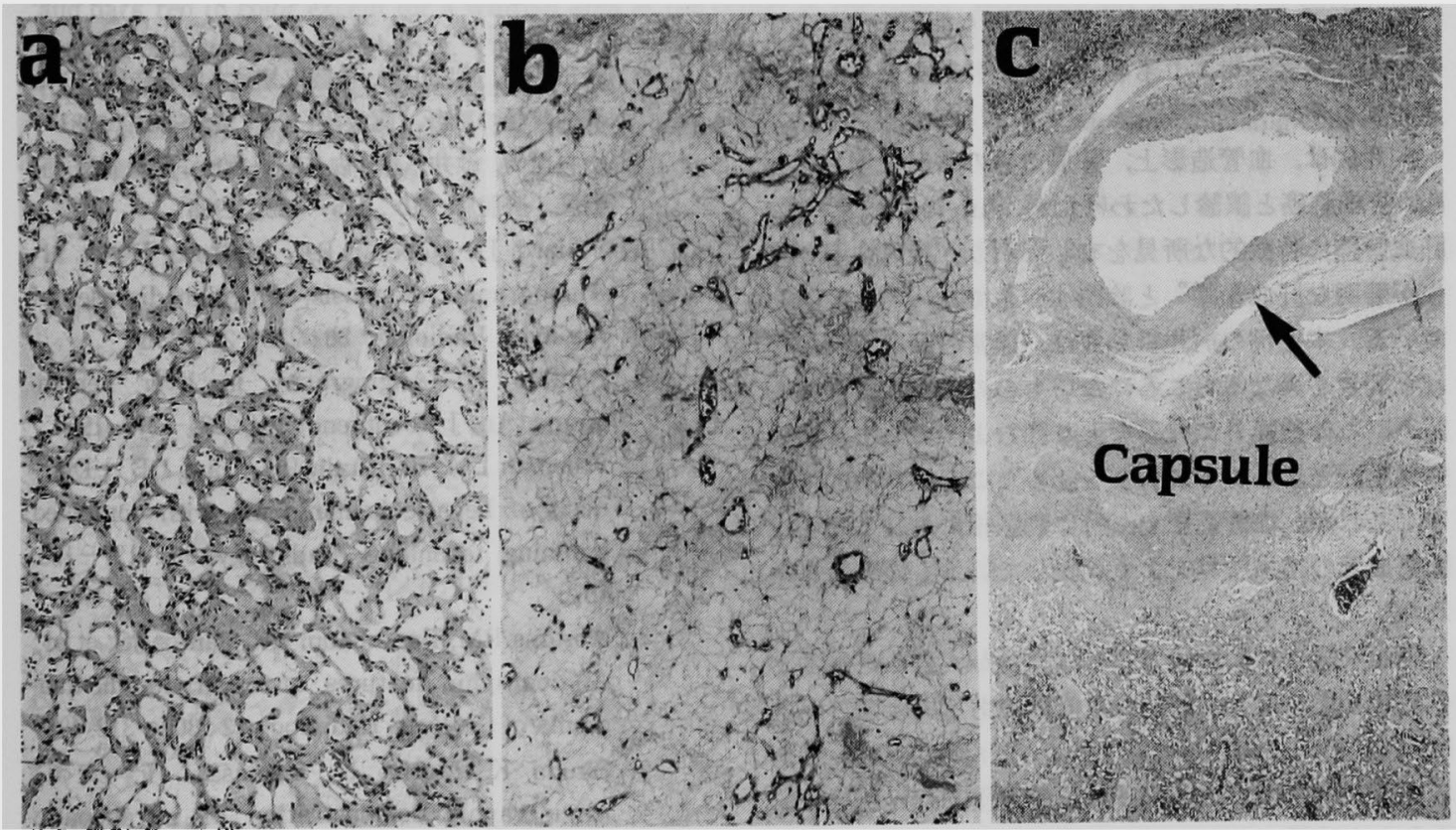

図 6a, b, c 病理組織所見：a：腫瘍周辺部で海綿状血管尰の像を認める。(H.E. 染

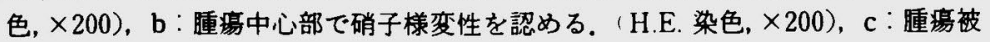
膜近傍で動脈枝（`）を認める.（H.E. 染色, ×40） 
分は，先迈した血管造影上の特致的所見を有しており， その診断は比較的容易であると言えよう。しかし，本 症例では，静脈相における不整な腫瘍謴染の程度か， 肝細胞癌に比べやや強い上らにも思われるが，血管腫 に特徽的ないわゆる“cotton wool”の所見 ${ }^{122}$ はなく， また，動脈相における畽煬血管の著明な増生は，retrospective に見ても肝細胞癌の動脈相の所見と区別する のは困難であると考えられた。

最近, 肝血管腫の診断法として, bolus 注入による Dynamic CTの有用性が数多く報告されてい $る^{124) 1 .}$. 肝血管隀の Dynamic CT 像は，造影直後より 周辺部が部分的ないし環状に浱染され，時間の経過と 共にその濃染が中心部に向って抾がってゆくといら特 敂的所見を呈する(1411). 肝細胞癌では, bolus 注入直後

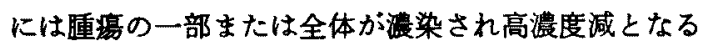
が，経時的に高濃度域が拗がらず，低濃度域に移行す ることから肝血管腫と鑑別できるとされているい12). Itai ら"1は, 12例の肝海線状血管稙全体に, 石口ら”は, 38例中37例にこの特徵的所見を認めたと報告し，それ ゆえ訮血管隀の診断は，ほとんどCTのみで可能であ $\eta, 1 \mathrm{~cm}$ 以下の小病変や診断がつけにくい症例にのみ 血管造影の猃断的価值があるとしているい1!．石口ら" は, Dynamic CT は, 肝血管腫に特徽的な腫場内の血 行動態をよく反映しており，横断面を観察できるCT の方か，血管造影よりも容易にその特徵をとらえると 述べている。

本症例は，血管造影上，畽場血管の著明な增生を認 め, 肝細胞癌と誤診したわけだか，Angio-CT 像では， 肝血管腫に特徵的な所見を有しており，“腫煌血管の増 生が著明な肝血管睡”と診断すべきであったと反省し ている. 本症例の病理組織像は, 通常の肝血管畽のそ れと大きく異なるところはないものの，明瞭な被膜を 認め, この被膜外に畽瘍をとり囲むよ5にして多数の 栄羡動脈と思われる動脈枝を認めたことが特徵的であ クこれが，血管造影上，特に動脈相における著明な 尰湯血管の増生所見をよく反映しているるのと考えら れた。

肝血管腫の手術適応として，畽場が大きくそれによ る症状のある場合, 破裂の可能性のある場合などがあ け゚られるが，一定した基隼は，またないようであ $3^{13) 14)}$. 本症(例は, 血管造影上, 最大径 $90 \mathrm{~mm}$ と比較的 大きな血管睡であったが，無症状であり，また，右尾 状葉といら肝の深部に存在していたことから，破裂の 可能性は極めて少ないと考えられる。しかし，中肝静
脈は腫婸によりほぼ完全に閉塞しており，また，右お よび左肝轷脈む畽昜により正排されていた（手術時， 特に右肝静脈との㓦離が困難であったりことから、こ のまま放笡すれば，3本の主肝静脈のすへてが狭窄す しくは閉塞されることす予想されよう。本症例の手街 術式は, 尾状葉十左葉内側区十右葉前上区域切除術之 いら非定型的かつ複雑なるのであったか，切除の意義 はあったすのと考皇ている。

\section{結 語}

1）血管造影上,肝細胞癌に類似した肝血管腫の 1 七刀 除例を報告した。

2）血管造影上，睡揚血管の增生が著しく，肝細胞癌 に極めて類似した所見を呈する肝血管腫が存在する点 に留意すべきである。

本論文の要旨は第27回日本消化器外科学会 (於, 米子市) にて吠表した.

\section{文献}

1) 大石 元, 黑田知純, 中尾宣夫他: 肝血管腫, 肝胆 ・膵一確定診断への画像的接近と診断手技の治 療的応用一, 打田日出夫編, $\mathrm{p} 77-88$, 医学甾院, 東京, 1984

2) Mcloughlin MJ : Angiography in cavernous hemangioma of the liver. Am J Radiol 113: 50 $-55,1971$

3）森田楥，篠原正裕，佐藤直樹他：血管造影棌よる 肝血管腫の診断，臨放線 $26: 375-381 ， 1981$

4) 石口亘男, 改井位, 佐久間貞行他: 肝血管腫, 肝

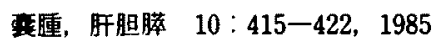

5) Pollard JJ, Nebesar RA, Mattoso JF, et al: Angiographic diagnosis of benign diseases of the liver. Radiology $86: 276-283,1966$

6) Pontajo E: Angiography in liver hemangioma. Am J Roentgenol 104 : 874-879, 1968

7) Freeman LM, Bernstain RG, Hayt DB : Diagnosis of hepatic hemangioma with combined scanning technique. Radiology 95: 127-128, 1970

8) Abrams RM, Beranbaum ER, Santos JS, et al : Angiographic features of cavernous hemangioma of the liver. Radiology 92 : 308-312, 1969

9) Okuda K, Musha $H$, Yamasaki $T$, et al: Angiographic demonstration of intrahepatic arterio-portal anastomoses in hepatocellular carcinoma. Radiology $122: 53-58,1977$

10）有山 裹, 幕内雅敏, 武藤晴臣他：小肝細胞癌の進 
展度判定と治療, 腹部画像䇏断 $5: 517-538$, 1985

11) Itai $Y$, Furui $S$, Araki $T$, et al: Computed tomography of cavernous hemangioma of the liver. Radiology $137: 149-155,1980$

12）中村信, 田中 健, 崔 秀美他：肝細胞癌の CT
一その特徽 CT 像と転移性腫楊との鑑別一，臨放

線 $27: 601-607,1982$

13）葛西洋一，圆谷敏彦，柿田 章他：良性連場の手術 適応，肝胆勝 $6: 7-12,1983$

14）木村泰三，渡辺五郎，万代恭嗣他：肝海綿状血管腫 の診断と治療, 外科 $43: 1427-1433,1981$

\title{
A RESECTED CASE OF CAVERNOUS HEMANGIOMA SITUATED IN THE RIGHT CAUDATE LOBE OF THE LIVER DIFFICULT TO DIFFERENTIATE FROM HEPATOMA
}

\author{
Masato NAGINO, Shigehiko KONDOH, Michio KANAI and Kohei MORI \\ Department of Surgery, Daidoh Hospital
}

Yuji NIMURA, Hiroo MUKAIYAMA and Junichi KAMIYA

1st Department of Surgery, Nagoya University School of Medicine

A 56-year-old female complaining of macrohematuria was accidentally found to have a liver tumor by ultrasonography. Selective celiac angiography showed a hypervascular hepatic lesion with haphazard marked neovascularity, dilated feeding artery and mottled tumor stain, $90 \mathrm{~mm}$ in diameter, in the middle and cranial portion of the liver. On angio-CT, dense accumulation of contrast material near the periphery of the lesion in early contrast scan, accumulation spreading toward the center of the tumor with time, and marked reduction of the low density area in the late scan were recognized. The lesion was diagnosed as hepatoma as a result of the findings on angiography, although hemangioma was strongly suggested by angio-CT.

At laparotomy the tumor was found in the right caudate lobe, and extended medial segmentectomy (caudate, middle and right anterosuperior segments) was performed. The cut surface of the resected specimen was spongy and dark red in color except for a whitish area at the center of the tumor. Histologically it was liver cavernous hemangioma without malignancy. The fact that many abnormal arteries were recognized near the capsul of the tumor reflected the findings of neovascularity on angiography.

We should pay careful attention to differential diagnosis between hepatoma and hemangioma with neovascularity on angiography. 